\title{
FIRST RECORD OF CAREBARA OERTZENI FOREL, 1886 (HYMENOPTERA: FORMICIDAE) FROM ALBANIA
}

\section{Adrián Purkart*, Daniel Jablonski \& Jana Christophoryová}

Department of Zoology, Faculty of Natural Sciences, Comenius University in Bratislava, Mlynská dolina B-1, Ilkovičova 6, SK-842 15, Bratislava, Slovakia

Purkart, A., Jablonski, D. \& Christophoryová, J.: First record of Carebara oertzeni Forel, 1886 (Hymenoptera: Formicidae) from Albania. Nat. Croat. Vol. 28, No. 1., 173-176, Zagreb, 2019.

The first record of the rare ant Carebara oertzeni Forel, 1886 from Albania is reported. Two workers of $C$. oertzeni were discovered in the south-eastern part of the country, near the village of Benjë-Novoselë. So far, it is the northernmost known distribution of this very rarely collected species, the sole representative of its genus in Europe, whose previous records all come from Greece and Turkey. In addition, we also found a specimen determined as the Proceratium melinum Roger, 1860 worker ant in the same soil sample.

Key words: ants, Balkans, Carebara oertzeni, distribution, Formicidae

Purkart, A., Jablonski, D. \& Christophoryová, J.: Prvi nalaz vrste Carebara oertzeni Forel, 1886 (Hymenoptera: Formicidae) iz Albanije. Nat. Croat. Vol. 28, No. 1., 173-176, Zagreb, 2019.

Rad donosi prvi nalaz rijetke vrste mrava Carebara oertzeni Forel, 1886 iz Albanije. Dva radnika pronađena su u jugoistočnom dijelu zemlje, blizu sela Benjë-Novoselë. Dosad je to najsjevernija točka $\mathrm{u}$ rasprostranjenosti ove rijetko pronalažene vrste, jedinog predstavnika tog roda u Europi; prethodni nalazi potječu iz Grčke i Turske. Osim toga u istom uzorku tla pronađen je primjerak radnika vrste Proceratium melinum Roger, 1860.

Ključne riječi: mravi, Balkan, Carebara oertzeni, rasprostranjenost, Formicidae

With fewer than 80 known species (Agosti \& Collingwood, 1987a; Andoni, 1993; Borowiec, 2014; WAGNer et al., 2018) and the lack of a national checklist, the Albanian myrmecofauna is one of the most unexplored in Europe. Herein, we report the discovery of the tiny and rare Mediterranean species Carebara oertzeni Forel, 1886 in South-eastern Albania.

Two C. oertzeni workers (Fig. 1) were collected in the South-Eastern Albanian locality of Benjë, near Benjë-Novoselë $\left(40^{\circ} 14^{\prime} 34.512^{\prime \prime} \mathrm{N}, 20^{\circ} 25^{\prime} 46.451^{\prime \prime} \mathrm{E}\right.$, ca. $336 \mathrm{~m}$ a.s.l., South-eastern Albania, Fig. 2, leg. J. Christophoryová \& D. Jablonski, 30.IV.2016, det. A. Purkart). This locality is situated next to a canyon of the river Lengaricës, where rocky slopes are covered with small areas of forest-steppe (Fig. 3). Both C. oertzeni specimens were retrieved from a sample of rotten wood, leaf litter and soil taken from a decaying tree, and the collected material was then heat extracted from the sample using Tullgren funnels. One specimen determined as a worker of Proceratium melinum Roger, 1860 (Baroni Urbani \& De Andrade, 
2003) was found in the same sample. Carebara oertzeni workers were identified following the key provided by Agosti \& Collingwood (1987b) and the worker description by Karaman \& Kiran (2017). The specimens were then deposited at the Department of Zoology, Faculty of Natural Sciences, Comenius University, Bratislava (the Slovak Republic).

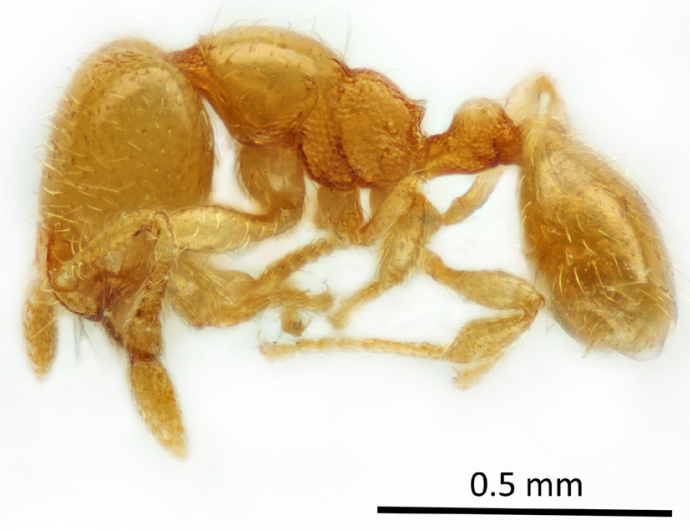

Fig. 1. Carebara oertzeni (Forel, 1886) worker from Benjë, Albania - lateral view.

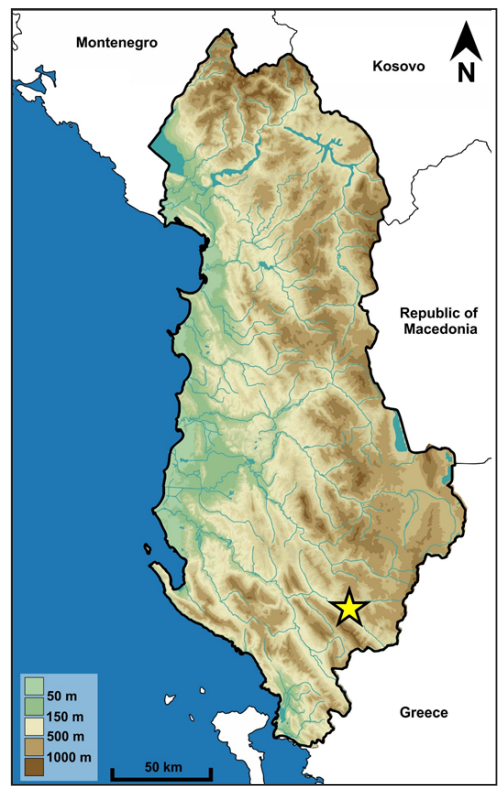

Fig. 2. The position of the locality Benjë within Albania where the individuals were recorded (yellow star).

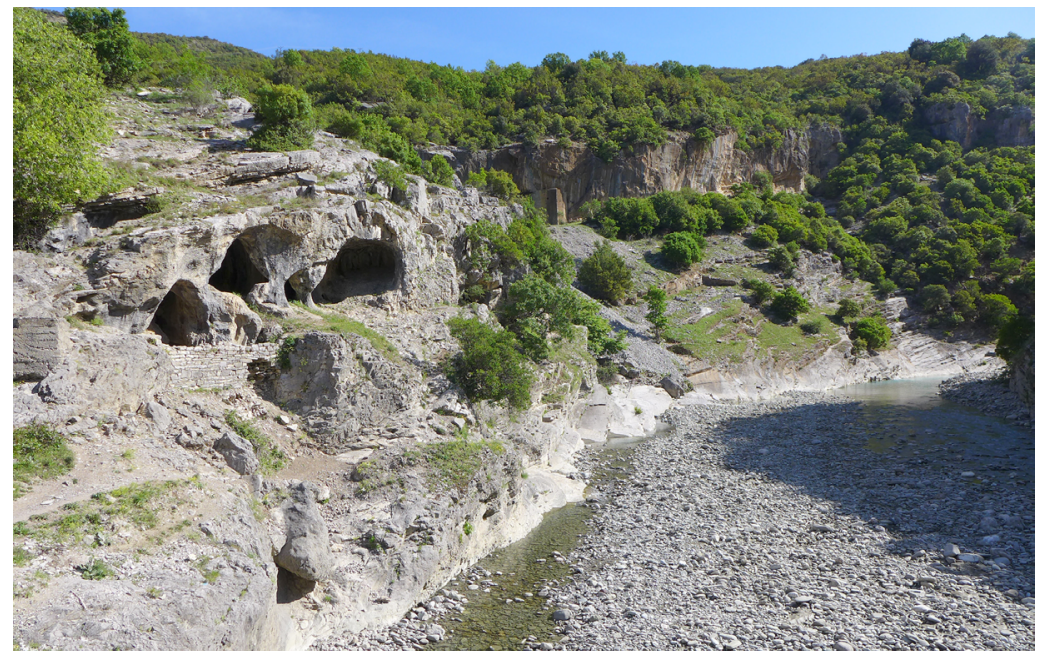

Fig. 3. Habitat of Carebara oertzeni next to the river, Benjë, Albania (Photo: J. Christophoryová, 2016). 
Although the ant genus Carebara Westwood, 1840 (sensu Fernández (2004, 2010); Fisher et al. (2014) contains more than 200 described species (Bolton, 2018) and is widely distributed in subtropical and tropical regions, Carebara oertzeni is the only species of the genus occurring in Europe. It is very rarely collected and was previously known only from Greece and Turkey (Karaman \& Kiran, 2017; Borowiec \& Salata, 2018; Salata \& Borowiec, 2018). In addition, the validity of its C. oertzeni aeolia Forel, 1911 subspecies from Turkey remains disputed, and this issue requires further studies (Borowiec, 2014; Karaman \& Kiran, 2017). Most members of the genus Carebara are very small subterranean ants that are often associated with decaying wood and leaf litter (Aldawood et al., 2011; BHARTi \& Kumar, 2013; Niba \& Yekwayo, 2016). However, very little information is available on their natural history because of their often cryptic lifestyle, and C. oertzeni had only previously been reported from the outer wall of an adobe house (KARAMAN \& Kiran, 2017) and at the foot of oleanders (Borowiec \& Salata, 2018). Therefore, our Albanian Benjë discovery near the canyon of the Lengaricës River extends the knowledge of its ecological presence in natural habitats.

Increased use of Tullgren funnels, Winkler sacks and other sampling techniques for endogean ants should prove beneficial in the future study of European ants (Bestelmeyer et al., 2000). This is also essential because the perceived rarity of many ant species and lack of data on their actual distribution appears to be linked to inadequate sampling techniques (EsPADALER \& López-Soria, 1991). Finally, this approach should prove quite successful in the special case of $C$. oertzeni, because extensive efforts are required for the better understanding of the the distribution and ecological traits of this enigmatic species.

\section{ACKNOWLEDGMENTS}

We are very grateful to Ján Kodada (Bratislava, Slovakia) for his help in photographing the specimen. The research was financially supported by VEGA Projects 2/0012/17 and 2/0032/19 and by the Slovak Research and Development Agency under Contract No. APVV-15-0147.

Received February 25, 2019

\section{REFERENCES}

Agosti, D. \& Collingwood, C. A., 1987a: A provisional list of the Balkan ants (Hym,. Formicidae) with the key to the worker caste. I. Synonimic list. Bulletin de la Société Entomologique Suisse $60,51-62$.

Agosti, D. \& Collingwood, C. A., 1987b: A provisional list of the Balkan ants (Hym., Formicidae) with the key to the worker caste. II. Key to the worker caste, including the European species without the Iberian. Bulletin de la Société Entomologique Suisse 60, 261-293.

Aldawood, A.S., Sharaf, M.R. \& Taylor, B., 2011: First record of the Myrmicine ant genus Carebara Westwood, 1840 (Hymenoptera, Formicidae) from Saudi Arabia with description of a new species, C. abuhurayri sp. n. ZooKeys 92, 61-69.

Andoni, V., 1993: Species composition, geographical distribution and some bioecological data for ants of the genus Formica (Hymenoptera-Formicidae) of Albania. Biologia Gallo-Hellenica 20, 199-208.

Baroni Urbani, C. \& De Andrade, M.L., 2003: The ant genus Proceratium in the extant and fossil record (Hymenoptera: Formicidae). Museo Regionale di Scienze Naturali, Monografie 36, 1-492. 
Bestelmeyer, B.T., Agosti, D., Alonso, L.E., Brandão, C.R.F., Brown, W.L., Jr, Delabie, J.H.C. \& Silvestre, R., 2000: Field techniques for the study of ground-dwelling ants: an overview, description and evaluation. In: Agosti, D., Majer, J., Alonso, L.E., Schultz, T. (eds): Ants: Standard Methods for Measuring and Monitoring Biodiversity. Washington DC, USA: Smithsonian Institution Press, 122-144.

Bharti, H. \& Kumar, R., 2013: Six New Species of Carebara Westwood (Hymenoptera: Formicidae) with Restructuring of World Species Key to Indian Species. Journal of Entomological Research Society 15, 47-67.

Bolton, B., 1973: The ant genera of West Africa: a synonymic synopsis with keys (Hymenoptera: Formicidae). Bulletin of the British Museum (Natural History), Entomology 54, $263-452$.

Bolton, B., 2018: An online catalog of the ants of the world. <http://antcat.org accessed at: 2018.08.22.>

Borowiec, L., 2014: Catalogue of ants of Europe, the Mediterranean Basin and adjacent regions (Hymenoptera: Formicidae). Genus. Special issue - Monograph 25(1-2), 1-340.

Borowiec, L. \& Salata, S., 2018: Notes on ants (Hymenoptera: Formicidae) of the Euboea Island, Central Greece. Annals of the Upper Silesian Museum in Bytom, Entomology 27 (online 005), 1-15.

Espadaler, X. \& López-Soria, L., 1991: Rareness of certain Mediterranean ant species, fact or artifact?. Insectes Sociaux 38, 365-377.

Fernández, F., 2004: The American species of the myrmicine ant genus Carebara Westwood. Caldasia 26, 191-238.

Fernández, F., 2010: A new species of Carebara from the Philippines with notes and comments on the systematics of the Carebara genus group (Hymenoptera: Formicidae: Myrmicinae). Caldasia 32, 191-203.

Fischer, G., Azorsa, F. \& Fisher, B.L., 2014: The ant genus Carebara Westwood (Hymenoptera, Formicidae): synonymisation of Pheidologeton Mayr under Carebara, establishment and revision of the C. polita species group. ZooKeys 438, 57-112.

Kiran, K. \& Karaman, C., 2012: First annotated checklist of the ant fauna of Turkey (Hymenoptera: Formicidae). Zootaxa 3548, 1-38.

Karaman, C. \& Kiran, E., 2017: First record of Carebara oertzeni Forel (Hymenoptera: Formicidae) from the European part of Turkey with worker description. Turkish Journal of Zoology 41, 638-644.

Niba, A.S. \& Yекwayo, I., 2016: Epigaeic invertebrate community structure in two subtropical nature reserves, Eastern Cape, South Africa: Implications for conservation management. Arachnology Letters 52, 7-15.

Salata, S. \& Borowiec, B., 2018: Taxonomic and faunistic notes on Greek ants (Hymenoptera: Formicidae). Annals of the Upper Silesian Museum in Bytom, Entomology 27(008), 1-51.

Wagner, H.C., Seifert, B., Borovsky, R. \& Wolfgang, P., 2018: First insight into the ant diversity of the Vjosa valley, Albania (Hymenoptera: Formicidae). Acta ZooBot Austria 155, 315-321. 